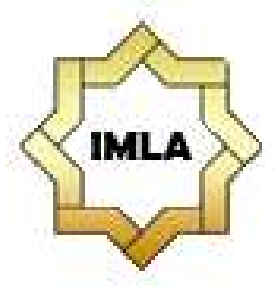

\author{
Al-Ta'rib \\ Jurnal Ilmiah Program Studi Pendidikan Bahasa Arab \\ IAIN Palangka Raya \\ Vol. 9, No. 1, June 2021, 25-34 \\ p-ISSN 2354-5887 | e-ISSN 2655-5867 \\ https://doi.org/10.23971/altarib.v9i1.2522
}

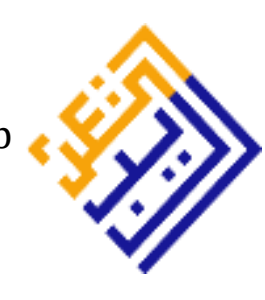

\title{
IS HISTORICAL STUDY OF NAHWU ON MADRASAH BASRA AND KUFA IMPORTANT TO TEACH? THE ANALYSIS OF OPINION ON INDONESIAN AFL STUDENTS
}

\author{
Ulfa Febriyanti', Maman Abdurrahman'2, Asep Sopian ${ }^{3}$ \\ 1,2,3Universitas Pendidikan Indonesia \\ E-mail: ulfafebriyanti@upi.edu
}

\begin{abstract}
The knowledge of nahwu has been taught in many universities in Indonesia. However, the study of the nahwu taught is still limited to a study oriented to the science of tools in learning Arabic and ignores historical, theoretical aspects such as Madrasah Basra and Kufa. Therefore, this study aims to prove whether this historical, academic study is essential to be taught to Indonesian AFL students. This research uses a quantitative approach with a descriptive type. The questionnaire was given to several 20 fifthsemester AFL students with three open-ended questions about their knowledge of Madrasah Basra and Kufa. The results of this study indicate that $60 \%$ of students are familiar with Madrasah Basrah and Kufa. Most of them hear about Madrasah Basrah and Kufa for the first time in college (75\%), in pesantren (8.3\%), on the internet (8.3\%), at high school (8.3\%), and from the sermon (8.3\%.). Moreover, the students generally know about Madrasah Basrah and Kufa's differences, but it is only limited to the differences in terms and I'rab. Therefore, the learning of nahwu needs to be developed by paying attention to the historical aspects of the nahwu development, especially the differences from Madrasah Basrah and Kufa.
\end{abstract}

Keywords: Nahwu; Basra and Kufa; Arabic language

\section{Abstrak}

Ilmu nahwu sejatinya telah diajarkan di banyak Perguruan Tinggi di Indonesia. Namun, kajian ilmu nahwu yang diajarkan tersebut masih sebatas kajian yang berorientasi pada ilmu alat dalam mempelajari bahasa Arab dan kurang memperhatikan aspek teoritis historis seperti Madrasah Basra dan Kufa. Maka dari itu, penelitian ini bertujuan untuk membuktikan apakah kajian teoritis historis tersebut penting untuk diajarkan pada mahasiswa AFL Indonesia. Penelitian ini menggunakan pendekatan kuantitatif dengan jenis deskriptif. Kuesioner diberikan kepada sejumlah 20 mahasiswa AFL semester lima dengan tiga pertanyaan terbuka seputar pengetahuan mereka tentang madrasah Basra dan Kufa. Hasil penelitian ini menunjukkan bahwa 60\% mahasiswa sudah mengenal madrasah Basrah dan Kufah, sebagian besar pertama kali mendengarnya di perguruan tinggi (75\%), pesantren (8,3\%), internet (8,3\%), SMA (8,3\%), dan pengajian (8,3\%.). Selain itu, mahasiswa pada umumnya mengetahui tentang perbedaan madrasah Basra dan Kufa namun hanya sebatas pada perbedaan istilah dan I'rab. Maka dari itu, pembelajaran tentang 
ilmu nahwu perlu dikembangkan dengan memperhatikan aspek kajian historis dari perkembangan ilmu nahwu khususnya pada perbedaan dari madrasah Basra dan Kufa.

\section{Kata kunci: Nahwu; Basra dan Kufa; Bahasa Arab}

\section{Introduction}

Islamic figures and circles at the time of the Prophet Muhammad's Companions were concerned about errors in language practice. These errors often occurred when reciting the al-Qur'an. As a result of this concern, some figures took the initiative to find solutions to overcome these errors' problems. From the historical tracing results, it was recorded that Abu Aswad Ad-Duali was a pioneer in providing initiatives by compiling the discipline of nahwu to overcome the problematic errors in language practice (Hazuar, 2019). On the other hand, several factors also contributed to the birth of nahwu, such as religious, social, political, racial, and ethnic factors. At that time, Arabians wanted to maintain their language of pride, Arabic (Taufik, 2020).

Experts say that the development of nahwu started from Basra, which then spread to Kufa and spread to Baghdad, Andalusia, and Egypt. These cities' geographical conditions respectively differ, resulting in the different points of view of the nahwu scholars in addressing the language problems. Meanwhile, the most significant development of nahwu came from the most popular madrasah, which is madrasah Basra and Kufa (Ihsanudin, 2017).

Several previous studies showed that there had been numerous studies discussing the history and differences in the characteristics of the two madrasahs. Mansur (2018) revealed that. ItKhalil bin Ahmed Al-Farahidi pioneered the development of Nahwu in Basra had specific factors such as accuracy and caution in selecting texts to determine grammar rules. On the other hand, madrasah Kufa was developed by al-Kasaei, and it had characteristics such as an extended analogy and a lot of leniency in grammar rules. The two madrasahs' characteristic differences have certainly been causing debate and opinion disparity between them (Mansur, 2018).

Ahmad (2020) also confirmed that the opinion differences between madrasah Basra and Kufa led to a bitter dispute as to what happened in the debate of al-Kisâ'î and Sibawaihi (Ahmad, 2020). The discussion eventually caused implications on the different perspectives of nahwu clerical figures and the current learning of Nahwu (Wahyudi, 2020). Jazuli and Mustofa (2017) mention that due to the differences between the two madrasahs (Basra and Kufa), various terms emerge from the rules of nahwu and the use of tafshil, which is difficult for Arabic learners to understand (Jazuli \& Mustofa, 2017). This indicates that historical studies related to the development of Nahwu become an essential thing for learners to learn and understand to avoid debates on these differences.

However, historical studies of nahwu were rarely taught in formal and informal education in Indonesia. Khalisin (2011) reports that nahwu learning in Indonesia is more oriented to being a tool in learning Arabic (Khalisin, 2011). Therefore, the books used as references mainly refer to the role of nahwu to aid in mastering Arabic. In contrast, theoretical historical materials tend to pay less attention to educational institutions. 
For Arabic linguists, nahwu learning from a historical perspective is essential since it is implicated in the accruing tolerance towards the term differences in nahwu within the learners. The result of preliminary observations showed several problems experienced by some Arabic language students (AFL) at one of the tertiary institutions in West Java, Indonesia, especially those related to the historical study of nahwu. The frequent problem lay in the difference of nahwu terms caused by Madrasah Basra and Kufa's disparate opinions, such as the naming term of adjective that is maushuf and na'at man'ut. Moreover, the rule distinction between the two madrasahs also made AFL students confused and question the truth. It occurred due to the lack of students' knowledge about historical studies of nahwu.

Based on the phenomenon mentioned above, this study aims to analyze AFL students' opinion if it is essential for them to understand the historical research of $n a h w u$, especially in the aspects of Madrasah Basra Kufa's difference. This study is expected to provide an overview of nahwu learning, which is focused on tools for learning Arabic and oriented to understanding nahwu as a whole.

\section{Method}

This research used a quantitative-descriptive approach. Data collection was done by using the nonprobability sampling technique. One of the nonprobability sampling techniques is the purposive sampling technique. The participants were 20 AFL students who were currently in the fifth semester or the third year. This choice was based on considering that they have studied several Arabic grammar topics in the previous semester.

The data collection technique was conducted by using a questionnaire given directly to the participants. The questionnaire was compiled using a screening model with two stages. First, the AFL students were given one closed question to determine their prior knowledge of Madrasah Basra and Kufa. Second, three open questions were blessed to find out 1) where AFL students knew the terms of Madrasah Basra and Kufa, 2) AFL students' comprehension of Madrasah Basra and Kufa, and 3) the urgency of comprehending Madrasah Basra and Kufa in learning nahwu for AFL students. A direct interview was also conducted with several students to strengthen the data obtained in this research.

This research used three data analysis techniques: 1) re-checking the data obtained from the questionnaire, 2) classifying the data from respondents' answers by providing codes and scores using the Likert scale to measure the opinion or perception of AFL students, and 3) processing the data in tabular form by calculating the frequency of each category.

\section{Result of the Study and Discussion}

Based on the obtained data regarding the opinion of AFL students towards Madrasah Basra dan Kufa, the following data were found:

\section{Students' Opinion towards Madrasah Basra and Kufa}

This study's results discussed the opinions of AFL students at one of the universities in West Java, Indonesia. Based on the data collected through the questionnaire, the following was the percentage distribution of the students' answers to the question, "Do you know the terms of Madrasah Basra and Kufa in Nahwu?" The percentage was provided in Graphic 1. 


\section{Graphic 1.}

\section{Students' Knowledge Related to the Term of Madrasah Basra and Kufa}

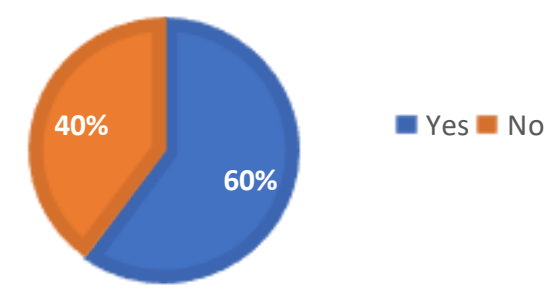

From Graphic 1 above, it was known that the tabulation of data on students who knew the terms Madrasah Basra and Kufa was 60\%. Meanwhile, $40 \%$ of students stated that they did not recognize those two terms of madrasah.

Arikunto (2011) categorizes the percentage of a person's knowledge level into three levels. First, the good category is within a value of $\geq 76-100 \%$. Second, the appropriate type is within a value of $60-75 \%$. Third, it falls into the poor category if it is $\leq 60 \%$ (Arikunto, 2011). Suppose the percentage of the AFL students' knowledge was analyzed based on this theory. In that case, the AFL students' understanding of Madrasah Basra and Kufa in Nahwu could be categorized in the appropriate category (60\%). The survey results proved that the AFL students' knowledge of the two madrasahs was not good. Despite the survey results, in the interview, several students revealed that the fifth semester AFL students had taken several nahwu courses in the previous semester. This fact proved that the theoretical historical study of nahwu had not been taught optimally.

Below was the percentage distribution of the AFL students' answers to the question, "Where do you learn the terms of Madrasah Basra and Kufa in Nahwu?" It was provided in Graphic 2.

\section{Graphic 2.}

\section{Students' Source of Madrasah Basra dan Kufa}

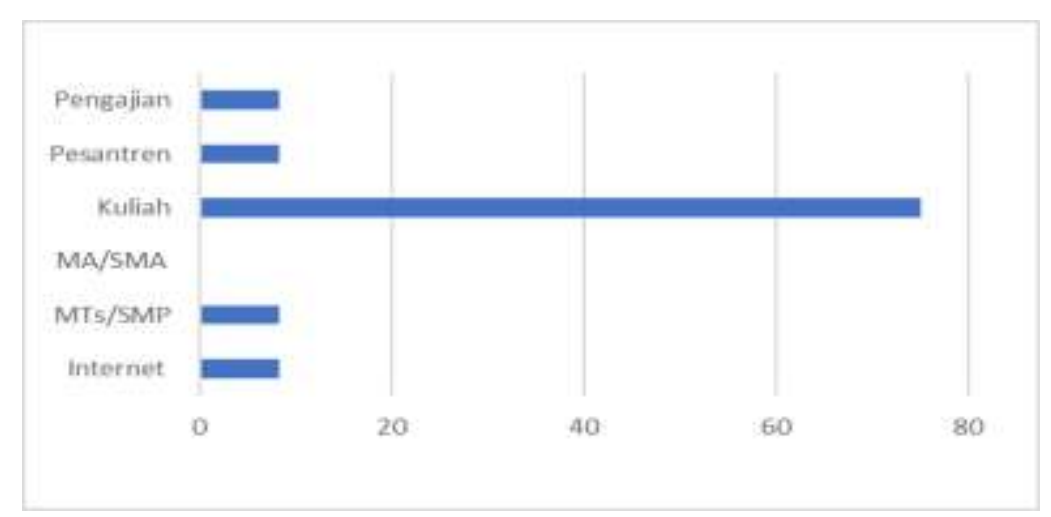

According to AFL students' answers, $75 \%$ of students described that they first obtained the term of Madrasah Basra and Kufa in Nahwu from lectures. On the other hand, $8.3 \%$ of students found out about the words from several sources, such 
as the internet, MTs/SMP (Junior High School), Islamic boarding schools (pesantren), and sermons.

Based on the interview results, it was found that AFL students at this tertiary institution had various backgrounds. Some students came from pesantren, and others came from public schools. This led to a reason why a considerable number of students did not aware of Nahwu's rules. This reason implied that most AFL students experienced difficulties in learning Arabic, especially in nahwu. Muammar (2018) reports that one of the factors of student difficulty in learning is the difference in students' educational background. Meanwhile, students who come from pesantren tend to understand the lessons better. It is in consideration of Arabic as the dominant subject studied in pesantren.

Dajani, Mubaideen also support this notion, and Omari (2014) that learning Arabic language skills is influenced by the learners' backgrounds' diversity. Considering that learning these differences is challenging, it is crucial to know the range of students willing to receive educational experiences and to know whether there is a harmonization between the features, materials, and methods used in teaching (Dajani et al., 2014).

The distribution of the percentage of students' answers to the question "What do you know about Madrasah Basra and Kufa?" was provided in Graphic 3.

Graphic 3.

\section{Students' Knowledge on the Difference between Madrasah Basra and Kufa}

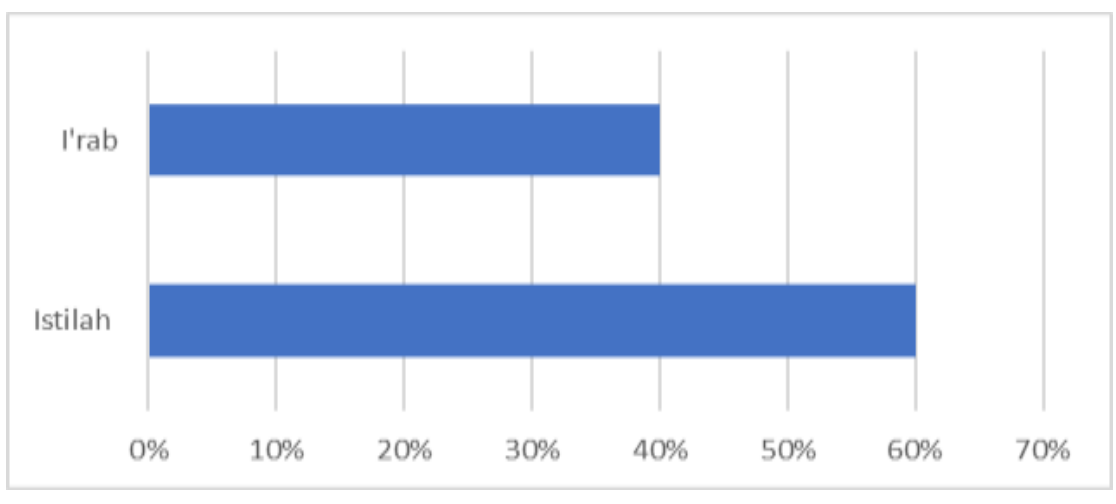

Two categories of AFL students' answers were obtained from the analysis of the open questionnaire. They were i'rab and terms in nahwu. The results showed that $60 \%$ of AFL students answered that the difference between the two madrasahs lay in the naming of terms in nahwu. For instance, the term al-jaar is used by Basra, whereas Kufa uses the time al-khafd. As for the remaining 40\%, the students reckoned that the difference was in the aspect of i'rab. For example, i'rab isim sittah. Kufa argues that isim sittah may be I'rabified with signs and harakat, whereas Basra can only I'rabify isim sittah with harakat. On the other hand, other problems also existed in the discussion of rafa 'mubtada' and isim. Basra argues that mubtada and khabar will mutually benefit each other, whereas Kufa considers that mubtada and khabar cannot be mutually beneficial.

However, AFL students had little or no knowledge of the two differences and did not fully understand the detailed differences in I'rab from Madrasah Basra and Kufa's perspectives. Based on the questionnaire results, it proved that theoretical 
historical material was rarely taught to AFL students. The knowledge of the history of madrasahs in nahwu and how the experts of nahwu formulated the rules was prone to get less attention. Therefore, it was not aligned with the theory described by Ramírez and Pons (2017). They reported that teaching history involved and motivated learners to think historically, to understand the methods to elaborate the knowledge, to recognize the values, to realize the influence on everyday life, and to consider the ethical attitudes and citizenship. It was all presented by discourses, and it involved thought-provoking processes that stimulated the learners' studies (Ramírez \& Pons, 2017).

To improve students' understanding of the historical discussion of $N a h w u$, the lecturers had a fundamental role in determining appropriate teaching methods and techniques. One of them was the use of repetition techniques that could encourage an enhancement of the learning process. It was aligned with the notion that the repetition technique was the mother of learning (Hamidin, 2015). The use of native language in grammar teaching became one of the methods educators use when dealing with language grammar aspects (Damra \& Al Qudah, 2012). Furthermore, As'ad et al. (2019) describe that the al-Qur'an verses have provided some essential guidelines to develop foreign language learning required by language educators. This issue was discussed comprehensively in various Qur'anic terms such as qawlan baliighan (effectivity), qawlan sadiidan (responsibility), qawlan ma'ruufan (feelings and social relations), and bilisaani qawmih (intellectuality and self-actualization). Albeit the terminology of al-Qur'an was more frequently used as the principle of communication, its impact in developing language teaching was also significant (As'ad et al., 2019).

On the contrary, Sehri (2011) argues that the teaching of nahwu requires innovation by expanding its studies, such as prioritizing some materials and delaying other materials. Moreover, teaching grammar methods were considered crucial for educators to ensure the mastery of Arabic language skills among learners. The use of accurate methods and techniques would contribute to successful teaching and learning (Hayisama et al., 2016). Learning strategies were also noteworthy for each learner. A language learner needed the language learner to make learning easier, faster, more enjoyable, and more effective to achieve specified results (Mulyani et al., 2020).

The distribution of students' answers to "the importance of knowledge about Madrasah Basra and Kufa in nahwu " was presented in Graphic 4.

\section{Graphic 4.}

\section{Students' opinion towards the Importance of Madrasah Basra dan Kufa}

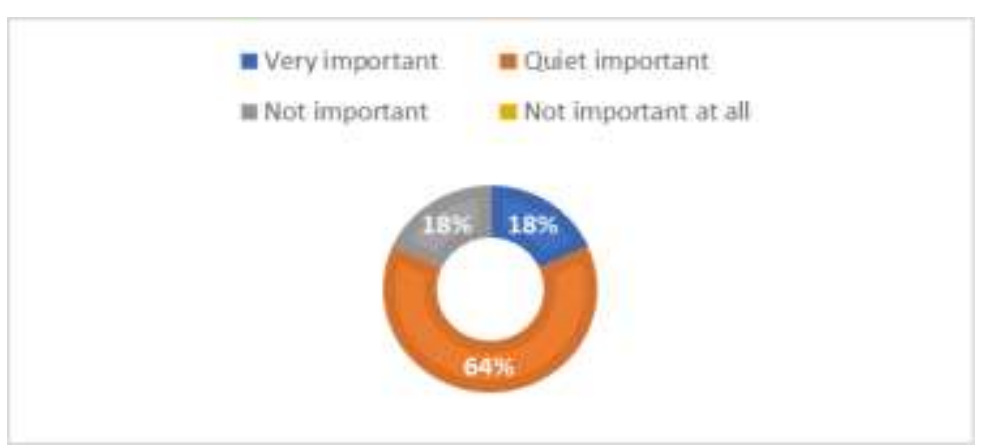

Jurnal Ilmiah Program Studi Pendidikan Bahasa Arab IAIN Palangka Raya Vol. 9, No. 1 / 25-34 Al-Ta'rib | p-ISSN 2354-5887 | e-ISSN 2655-5867 
Graphic 4. showed that $18 \%$ of AFL students considered that the knowledge of two madrasahs was not necessary, $18 \%$ of AFL students believed it was essential, and $64 \%$ put importance on both in learning nahwu. It meant that most of the AFL students found that Madrasah Basra and Kufa had significant differences in nahwu.

The result mentioned above was aligned with the research conducted by Jazuli and Mustafa (2017). They reported that many students from the Arabic Language and Literature Department in Malang had difficulty using grammatical rules. It was due to the large number of tafshil used in nahwu. It proved that Nahwu material was considered something difficult and tiring to learn (Hakim, 2014). Therefore, it is believed that the knowledge on the differences between Madrasah Basra and Kufa needs to be taught to AFL students from the first year. If students found different rules and terms when they learned nahwu, they could figure out early that it happened due to the ikhtilafat (differences) in the two madrasahs.

\section{Description of Nahwu learning according to Nahwu madrasahs}

Studying Nahwu madrasahs had positive implications for learning nahwu. The students would know the differences in Nahwu among nuhat (nahwu scholars). These differences could be in terms, methods, and cause-effects of khilafat among nahwu madrasahs. For instance, Madrasah Basra is inclined to try creating rules based on a considerable number of examples. Thus, Basra considered a few examples could not be used as evidence or thought it syaadz (something doubtful).

In contrast to Madrasah Basra, Madrasah Kufa preferred that correct language use is as original as narrated by the speaker, regardless of how doubtful (syaadz) the history was (Harianto, 2018). Fransisca (2015) concludes that Madrasah Basra seeks to have a system in language that can be rationalized and avoid all aspects of history (to determine language rules) that could disrupt the language system. On the other hand, Madrasah Kufa had the opposite characteristic. Everything uttered by the native Arab, regardless of the history's level of validity, could be used as a reference in deciding rules on the Arabic language.

In addition to the statement above, the students could also recognize renowned figures and their opinions, such as Abu Aswad Ad-Duali and Sibawaih from Madrasah Basra and Imam Al-Kisa'I from Madrasah Kufa, as well as the manifestations of disagreement between them. The students could discover the fundamental differences in nahwu and how the nuhats formulate nahwu rules.

It is known that nahwu has undergone developments. Several nahwu scientists have contributed to determining nahwu rules which have been studied to this day. It is also believed that the historical study of nahwu needs to be taught to students to discover the historical background of nahwu. The historical learning of nahwu, especially in Madrasah Basra and Kufa and their characters, can be introduced early. The explanation about conflicting rules between the two madzhabs can be delivered when discussing one of the rules in nahwu. The students are aware of the history of the rules' formulation.

\section{Conclusion}

Based on this study's results, it can be concluded that $60 \%$ of AFL students have already recognized the terms of Madrasah Basra and Kufa. From the percentage obtained, it can be inferred that the result is categorized as fair. $75 \%$ of AFL students acknowledge that the knowledge of Madrasah Basra and Kufa comes 
from lectures. The students' obtained knowledge on nahwu was $60 \%$ and on i'rab was $40 \%$. It can be concluded that most students have already known about Madrasah Basra and Kufa, even though their knowledge is only limited to the differences in terms of nahwu.

It is recommended that an overview of nahwu historical studies, such as the introduction of madrasahs and nahwu figures, is introduced in the first year. In contrast, the lessons about conflicting rules between madrasahs can be taught when studying nahwu rules. With this description, the students can learn the theoretical historical study of nahwu and its practices.

\section{References}

Ahmad, M. T. (2020). Isytiqoq Perspektif Aliran Basrah dan Kufah. IJAS: Indonesian Journal of Arabic Studies, 2(1), 73-90. https://doi.org/10.24235/ijas.v2i1.6286

Al-Anbaariy. Tt. al-Inshaaf fi Masaa'il al- Khilaf bain al-Nahwiyyin al-Basryyin wa alkufyyin, (Beirut Dar al-Fikr, $\mathrm{tt}$ ),

Arikunto, S. (2011). Prosedur Penelitian Suatu Pendekatan Praktik. Jakarta: Rineka Cipta.

As'ad, M., Muslim, A. B., \& Budiharjo, I. G. (2019). Qur'anic Perspective on Empowering Humanistic Foreign Language Teaching. Al-Bayan: Journal of Qur'an and Hadith Studies, 17(2), 168-194. https://doi.org/10.1163/22321969-12340074

Dajani, B. A. S., Mubaideen, S., \& Omari, F. M. A. (2014). Difficulties of Learning Arabic for Non-native Speakers. Procedia - Social and Behavioral Sciences, 114, 919926. https://doi.org/10.1016/j.sbspro.2013.12.808

Dajani, B. A. S., Mubaideen, S., \& Omari, F. M. A. (2014). Difficulties of Learning Arabic for non-native speakers. Procedia-Social and Behavioral Sciences, 114, 919926. https://doi.org/10.1016/j.sbspro.2013.12.808

Damra, H. M., \& Al Qudah, M. (2012). The effect of using native language on grammar achievement and attitudes toward learning of basic stages EFL students in Jordan. International Journal of Business and Social Science, 3(1). https://doi.org/10.30845/ijbss

Fransisca, T. (2015). Konsep I'rab dalam Ilmu Nahwu. Al Mahāra: Jurnal Pendidikan Bahasa Arab, 1(1), 79-100. https://doi.org/10.14421/almahara.2015.01104

Hakim, A. R. (2014). Mempermudah Pembelajaran Ilmu Nahwu pada Abad 20. Jurnal Al Maqayis, 1(1). https://doi.org/10.18592/jams.v1i1.96

Hamid, H. A. (2011). Perdebatan Nahwu Aliran Basrah dan Kufah dalam Konteks Sosial-Budaya dan Implikasinya dalam Pembelajaran Bahasa Arab. Research Collections.

Hamidin, N. M. (2015). Effective Technique of Teaching and Learning Arabic Language in the Classroom: A Case Study in Selected National Religious 
Secondary Schools (SMKA) In Selangor. International Conference on Language, Literature, Culture and Education. Selangor: Kolej Universiti Islam Antar Bangsa.

Harianto, N. (2018). Beberapa Perbedan Masalah-masalah Nahwu Antara Bashrah dan Kufah dalam Kitab Al-Inshaaf Fi Masaa'il Al-Khilaf Bain Al-Nahwiyyin AlBasryyin Wa Alkufyyin dan Dalil-Dalil Nahwu yang Digunakan. Tsaqofah dan Tarikh: Jurnal Kebudayaan dan Sejarah Islam,3(1), 39-48. http://dx.doi.org/10.29300/ttjksi.v3i1.1552

Hayisama-Ae, M., Zailaini, M., Wan Abdullah, W. M., \& Muzammil, A. (2016). Arabic Grammar Teaching Methods in University of Fatoni, Thailand. OIDA International Journal of Sustainable Development,9(02), 63-70. https://ssrn.com/abstract=2739884

Hazuar, H. (2019). Konsep I'rab Dalam Pandangan Ibrahim Musthafa dan Ibrahim Anis. Arabiyatuna: Jurnal Bahasa Arab, 3(1), 163-178. http://dx.doi.org/10.29240/jba.v3i1.796

Ihsanudin. (2017). Sejarah Perkembangan Mazhab Nahwu Arab (Sebuah Tinjauan Historis). Thaqafiyyat: Jurnal Bahasa, Peradaban, dan Informasi Islam. 18(1)

Jazuli, M \& Mustafa, A. (2017). Implikasi Madrasah Basrah dan Kufah Dalam Pembelajaran Di Indonesia. Seminar Nasional Bahasa Arab Mahasiswa I. Fakultas Sastra Universitas Negeri Malang.

Kholisin, K. (2011). Cikal Bakal Kelahiran Ilmu Nahwu. Bahasa dan Seni, 31(1).

Mansur. (2018). Pembelajaran Nahwu Basrah dan Kufah. IJ-ATL: International Journal of Arabic Teaching and Language. 2(2) https://doi.org/10.33650/ijatl.v2i2.421

Muammar, A. (2018). Persepsi Mahasiswa Terhadap Kuliah Bahasa Arab. TADARUS, 3(1).

Mulyani, E. R., Suherdi, D., \& Sundayana, W. (2020). Indonesia Islamic senior high school students' English learning conceptions and strategies. Indonesian Journal of Applied Linguistics, 9(3), 572-579. https://doi.org/10.17509/ijal.v9i3.23207

Ramírez, P. L. B., \& Pons, J. D. P. (2017). Development needs for teaching History of Cuba in university part-time courses with Blended Learning. In Proceedings of the 5th International Conference on Technological Ecosystems for Enhancing Multiculturality (pp. 1-7). https://doi.org/10.1145/3144826.3145445

Sehri, A. (2011). Metode Pengajaran Nahwu dalam Pengajaran Bahasa Arab. HUNAFA: Jurnal Studia Islamika, 7(1), 47-60. https://doi.org/10.24239/jsi.v7i1.108.47-60

Taufik, S. A., \& Taufik, M. A. (2020). Mazhab-Mazhab Ilmu Nahwu Dalam Sastra Arab Klasik. AL-AF'IDAH: Jurnal Pendidikan Bahasa Arab dan Pengajarannya, 4(1), 65-87. 
Wahyudi, H., Hidayat, H., \& Hakim, S. W. (2020). Pemikiran Gramatikal Bahasa Arab Oleh Linguistik Arab (Studi Tokoh Lintas Madzhab Nahwu). Al-Fikra: Jurnal Ilmiah Keislaman, 19(1). DOI: http://dx.doi.org/10.24014/af.v19i1.10235

\section{Copyright Notice}

Authors retain copyright and grant the journal right of first publication with the work simultaneously licensed under a Creative Commons Attribution 4.0 International License that allows others to share the work with an acknowledgement of the work's authorship and initial publication in this journal.

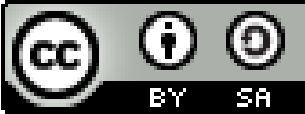

